УДК: 374:316.6:159.99

DOI: 10.26697/ijes.2019.4.3

\section{Управління самоосвітою викладачем системи мистецької освіти як тренд сучасності}

\section{Доцент Бриль М. М. ${ }^{1}$ \\ ${ }^{I}$ Київський національний університет культури $i$ мистеитвь, Україна}

\begin{abstract}
Резюме
Вступ:

Важливе значення в умовах реформування та трансформаційних суспільних змін сьогодення набуває управління системою самоосвіти педагогами, керування власною пізнавальною діяльністю. Робота 3 кадрами на рівні адміністрації неможлива без існування активної позиції педагога, самомотивації, систематичного вивчення та впровадження новітніх технологій в освітній процес. У цих аспектах викладач виступає суб'єктом саморозвитку. Гостру потребу в самоосвіті та управління нею відчувають й педагоги мистецьких закладів освіти.
\end{abstract}

\section{Результати:}

Термін життєдіяльності знань у багатьох галузях сьогодні складає від 1 до 5 років. Це викликає потребу постійного професійного вдосконалення та розвитку педагогічних працівників, які працюють на різних рівнях мистецької освіти. У процесі формування компетентного, конкурентоспроможного фахівця викладач мистецького закладу освіти майже щоденно зіштовхується зі зростаючими вимогами до власної діяльності (цифрова, інформаційна, комунікаційна, методологічна, психологічна, технологічна, мовленнєва, управлінська, інклюзивна компетентності). Важливим шляхом для вирішення ним зазначених професійних завдань стає самоосвіта, яка виступає оперативним чинником реакції фахівця на потреби професійного середовища. У 2017 р. Закон України “Про освіту” визначив самоосвіту як інформальну за змістом, тобто таку, яка передбачає самоорганізоване здобуття певних компетентностей під час діяльності. Критеріями необхідного рівня самоосвіти можна вважати сформульовані атестаційні вимоги, які Міністерство культури України затвердило для педагогічних працівників мистецької освіти в нормативних документах у 2018 р. Високі атестаційні критерії висуваються для всіх категорій педагогічних працівників, й, насамперед, суворі до тих, хто виконує в закладах освіти особливі освітні, як для здобувачів, так й для викладачів, методичні функції. Вимоги до викладачів-методистів досить ретельно потребують підтвердження високого рівня опановування методологічними навичками у викладанні та фахової презентації власного досвіду за п’ятирічний період праці в мистецькому освітньому закладі, які за міжатестаційний період можуть представлятися як: розроблення власного (авторського) методу, прийому, які викладач використовує у своїй педагогічній практиці; упорядкування/створення навчального репертуару/авторської постановки 3 дисципліни, яка викладається; розроблення навчального посібника/підручника, типової навчальної програми; створення авторської методики викладання. Такі завдання потребують від педагогічного працівника високого рівня рефлексії та педагогічної майстерності, які через розвиток самосвідомості, адекватний рівень домагань та самооцінки, ведуть через самопізнання та самоконтроль до саморозвитку. Траєкторії самоосвіти для педагогічного працівника виглядають досить широко та привабливо та спрямовані в цілому на вирішення подібних завдань. Так постанова Кабінету Міністрів № 800 від 21.08.19 p. про деякі питання підвищення кваліфікації педагогічних i науково-педагогічних працівників зазначає широкі можливості для підвищення кваліфікації: різноманітні інституційні форми (очні, заочні, дистанційні, мережеві, дуальні, на робочому місці); види (навчання, стажування, участь у практичних заходах); передбачає самостійність вибору форм, видів, напрямів, суб'єктів надання освітніх послуг; пропонує накопичувальну систему годин/кредитів, індивідуальність програм. Це дає впевненість щодо гнучкості в управлінні самоосвітою педагогами, які, як ми бачимо зовні (зацікавленість суспільства, адміністрації, нормативні акти), мають стимул до пошуків інноваційних методів у мистецькій освіті та виявлення нових можливостей іiі здобувачів. Однак, консервативність вітчизняної системи мистецької освіти, особливо початкової, стереотипність педагогічного сприйняття, низький рівень професійної самомотивації викладачів, упевненість у власній досконалості та бездоганності дещо стримують орієнтованість на розвиток. Тому питання самомотивації кожного викладача системи мистецької освіти зараз “на часі".

\section{Висновки: \\ Оновлення змісту мистецької освіти та сучасні зміни в ній не можуть залишати осторонь викладача й потребують його участі в управлінні самоосвітою та скоординованості цих дій на всіх ланках.}

\section{Інформація про автора: \\ Бриль Марина Миколаївна - кандидат} психологічних наук, доцент кафедри фешн- і шоубізнесу, Київський національний університет культури і мистецтв, Київ, Україна.

Наукові інтереси: освіта та навчання, соціальна психологія, методологія та теорія психології, психологічні технології, культура та мистецтво; https://orcid.org/0000-0003-1116-5823.

\section{Автор-Кореспондент:}

Бриль Марина Миколаївна

Email Автора-Кореспондента:

mbry173@gmail.com 